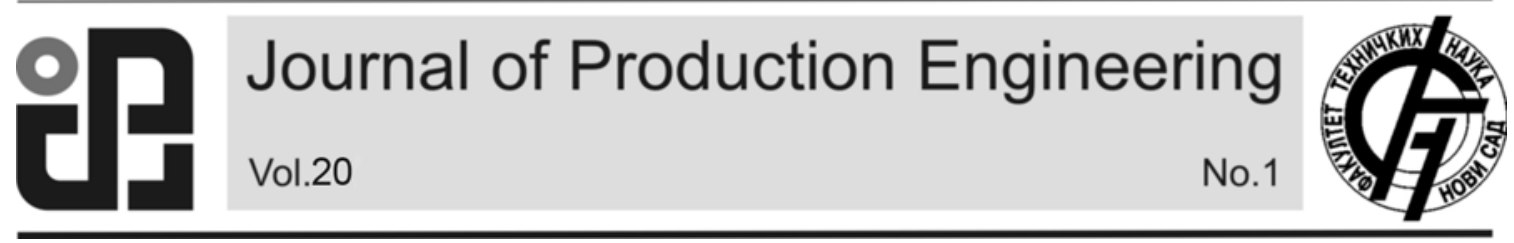

JPE (2017) Vol.20 (1)

Jindal, U., Jain, S., Piyush, Khanna, P.

Preliminary Note

\title{
MATHEMATICAL ANALYSIS OF VIBRATORY BOWL FEEDER FOR CLIP SHAPED COMPONENTS
}

Received: 15 March 2017 / Accepted: 16 April 2017

Abstract: In the present scenario, to meet the increasing demand of the consumers, the industries are adopting more and more automation to save time and money. Automation not only reduces human effort but also improves the quality of product and efficiency of production which is the need of the hour. Feeders play a major role in automation that helps to deliver the components in the desired orientation discretely. Present work aims at mathematical analysis of a vibratory bowl feeder for feeding clip shaped components. The path of the feeder was modified and the principle of center of gravity was used to feed the clips in desired orientation. A process model was formulated on the basis of Analysis of Variance (ANOVA) using Design-Expert Statistical Package.Interaction among the factors was studied and a full $2^{3}$ factorial experimental approach was adopted.

Key words: $A N O V A$, factorial experimental approach

Matematička analiza posude vibracionog snabdevača za komponente oblika spajalice. U prikazanom scenariju, da se zadovolji sve veća potražnja potrošača, industrija usvajaja sve više automatizacije da bi uštedili vreme $i$ novac. Automatizacija ne samo da smanjuje ljudski napor, ali i poboljšava kvalitet proizvoda $i$ efikasnost proizvodnje gledano na nivou od sat vremena. Hranilice igraju glavnu ulogu u automatizaciji koje pomažu da se komponente isporuče sa željenom orijentacijom diskretno. Ovaj rad ima za cilj da uz pomoću matematičke analize prikaže vibracije posude hranilice za komponente u obliku spajalice. Put hranilice je modifikovan i princip centra gravitacije se koristi za hranjenje spajalica u željenoj orijentaciji. Model procesa je formulisan na osnovu analize varijanse (ANOVA) upotrebom Dizajn-Ekpert statističkog paketa. Interakcija među faktorima je analizirana i puni $2^{3}$ faktorijalni eksperimentalni dizajn je usvojen.

Ključne reči: ANOVA, faktorni eksperimentalni pristup

\section{INTRODUCTION}

\section{What are feeders?}

Feeders form a critical part of automated assembly lines. Assembly processes demand the presence of components in desired amount and orientation. Feeders serve this purpose by feeding discrete parts to assembly cells on the production line from bulk and disoriented supplies [1].

\section{Need for optimization}

Part feeders are critical for automated assembly lines. Ad-hoc setting of parameters results in either starvation or saturation, where too less or too many parts are delivered to the work cells respectively [2]. Hence, optimization of feeders is a cause of concern. This project aims at mathematical analysis of a vibratory bowl feeder. Different input parameters were carefully chosen to establish the relationship between the system inputs and outputs.

\section{EXPERIMENTAL SETUP}

The existing path was modified to take care of the orientation of the clips. Centre of mass of the clips was used to sort the disoriented ones [3].

A cardboard setup consisting of a cut mark (as shown in figure 1) of the shape of the clip was designed with calculated cuts so as to sort the disoriented clips. Cardboard material was chosen so as to minimize the effect of vibrations that could fail the setup.

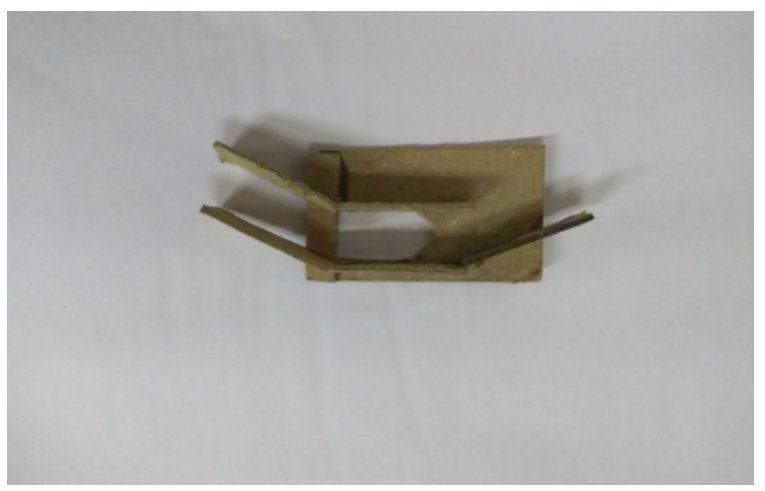

Fig. 1. Setup for feeding clip shaped components

Guiding paths were designed upto the cut mark and further beyond it in a proper manner to avoid jamming of the clips.

Further a simple chute was constructed to allow the clips to feed one at a time. Width of the chute was slightly greater than the width of the clips (as shown in figure 2).
2.1 Factors affecting the feed rate
1. Frequency of Operation $-55 \mathrm{~Hz}-75 \mathrm{~Hz}$
2. Part Population $-25-100$ 
3. Length of Clips $-28 \mathrm{~mm}-50 \mathrm{~mm}$

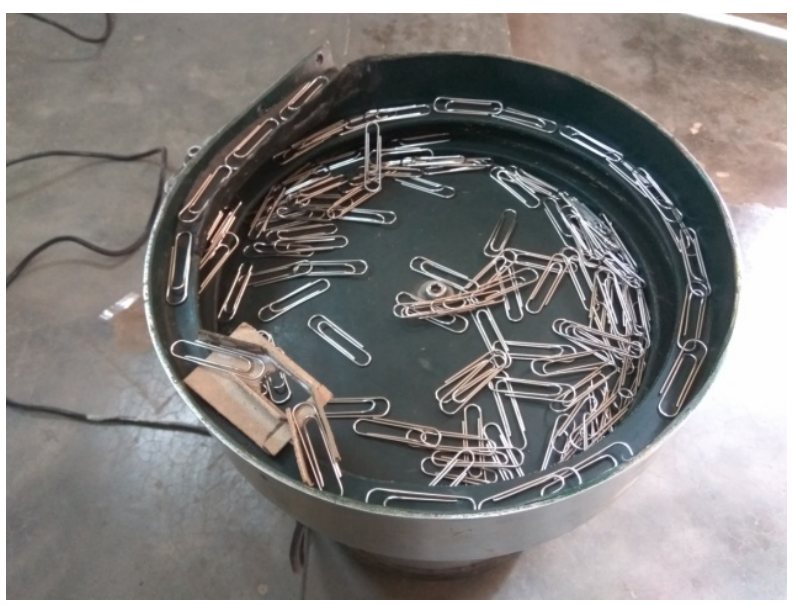

Fig. 2. Vibratory bowl feeder with modified path

\subsection{Factorial approach}

The aim of the experiment was to establish a statistical model to predict the output feed rate and its successful

optimization using $2^{\mathrm{k}}$ factorial design. The three factors chosen for experiment are the controllable variables which play a key role in the process characterization. These factors are varied within a controllable range purely on the experimental basis and feasibility [4].

Since there are three factors to be considered namely frequency of operation, part length and part population, the experiment design is called a $2^{3}$ full factorial design which required eight test runs, each with combinations of the three factors across two levels of each. Therefore, twenty four observations were taken in all to employ full factorial design as shown inTable1and Table2.

\begin{tabular}{|c|c|c|c|c|}
\hline $\begin{array}{l}\text { S } \\
\text { No }\end{array}$ & $\begin{array}{l}\text { Part } \\
\text { Length }\end{array}$ & Frequency & $\begin{array}{l}\text { Part } \\
\text { Population }\end{array}$ & $\begin{array}{l}\text { Feed } \\
\text { rate }\end{array}$ \\
\hline 1 & -1 & 1 & -1 & 31 \\
\hline 2 & 1 & -1 & -1 & 17 \\
\hline 3 & -1 & 1 & 1 & 51 \\
\hline 4 & 1 & 1 & -1 & 33 \\
\hline 5 & 1 & 1 & 1 & 50 \\
\hline 6 & -1 & -1 & 1 & 26 \\
\hline 7 & -1 & -1 & -1 & 15 \\
\hline 8 & 1 & -1 & 1 & 30 \\
\hline
\end{tabular}

Table 1. Range of parameters

\begin{tabular}{|l|l|c|c|}
\hline $\begin{array}{l}\text { S } \\
\text { No. }\end{array}$ & Parameter & $\begin{array}{l}\text { Low } \\
\text { Level (-1) }\end{array}$ & $\begin{array}{l}\text { High } \\
\text { Level (+1) }\end{array}$ \\
\hline 1 & Part Length (mm) & 28 & 50 \\
\hline 2 & Frequency (Hz) & 55 & 75 \\
\hline 3 & Part Population & 25 & 100 \\
\hline
\end{tabular}

Table 2. Range of Parameters in Actual Values

\section{ANALYSIS OF EFFECTS OF FACTORS ON FEED RATE}

\subsection{Cube Plot}

The cube plot for feed rate shows the average feed rates at the critical points which are those points where the parameters have their limiting values [5]. The vertices of the cube depict the maximum value of each of the parameters. Feed rate corresponding to any other combination of parameters lies within the cube as plotted in figure 3.
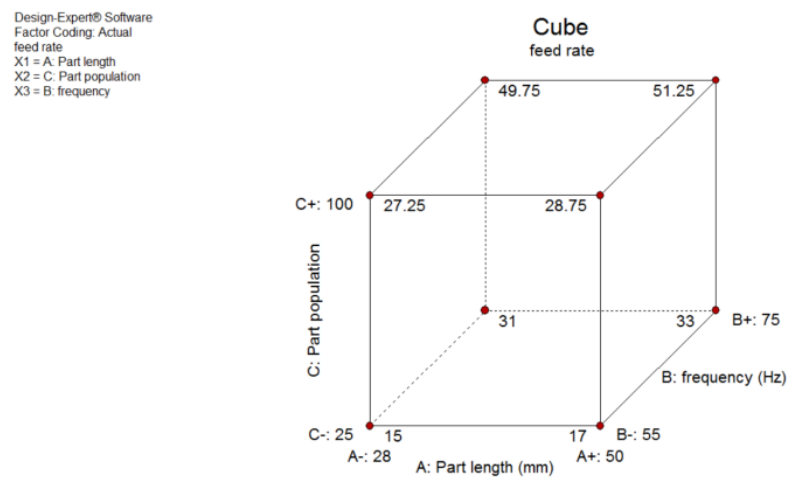

Fig. 3. Cube Plot (fitted means) for Feed rate

\subsection{One factor plots}

One factor plots are plotted as a simple two dimensional graph between two factors. The independent parameter is taken on the $\mathrm{x}$-axis while the dependent one on the y-axis.

Here the dependent parameter is the feed rate while the independent parameters are part population, part length and frequency of operation. The one factor graphs can be used to compare the relative strength of the effects across factors.

In the one-factor plots, only the first and the last readings are plotted and these are connected by a simple line as shown in figure 4,5 and 6 .

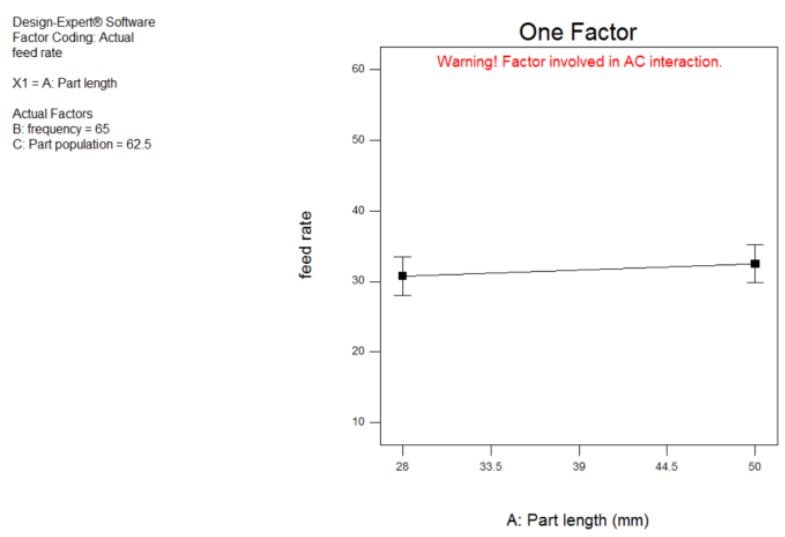

Fig. 4. Main Effects Plot (feed rate vs part length)

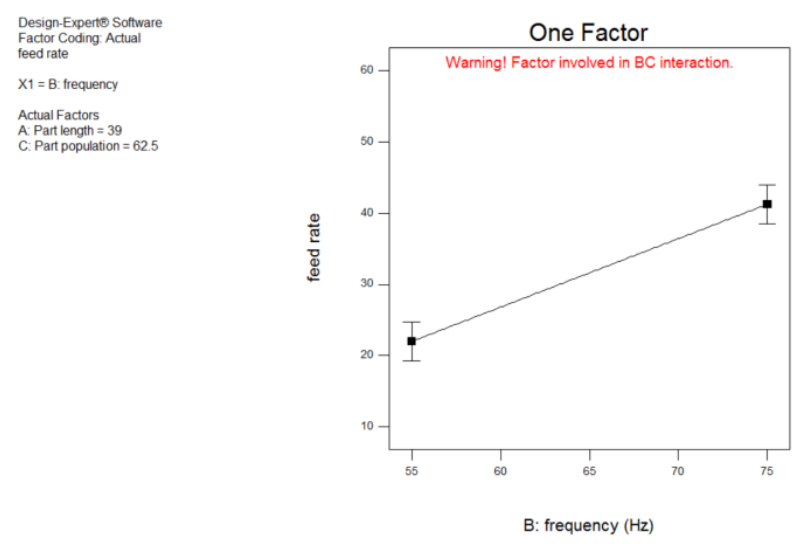

Fig. 5. Main Effects Plot (feed rate vs frequency) 


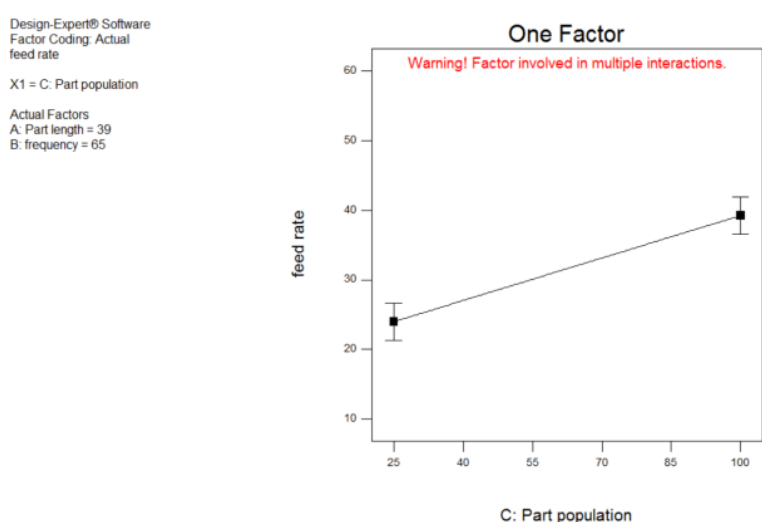

Fig. 6. Main Effects Plot (feed rate vs part population)

\subsection{Interaction plots}

Figures 7 and 8 depict a plot of average output for each level of two factors with the level of third and fourth factor held constant. These plots are used to interpret interaction between the process parameters. When the response at a factor level depends upon the levels of other factors, interaction is present. These interactions can either magnify or diminish the main effects of the parameters,hence, their evaluationis extremely important.

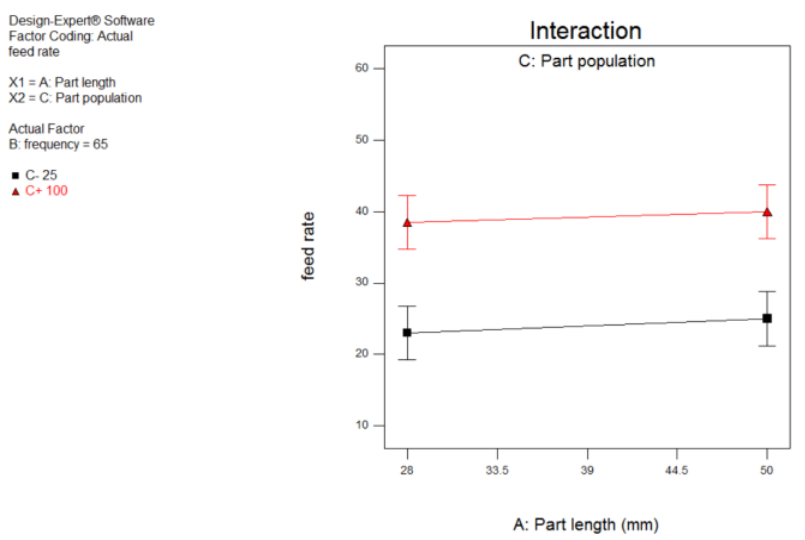

Fig. 7. Interaction Plot (part length \& Part population)

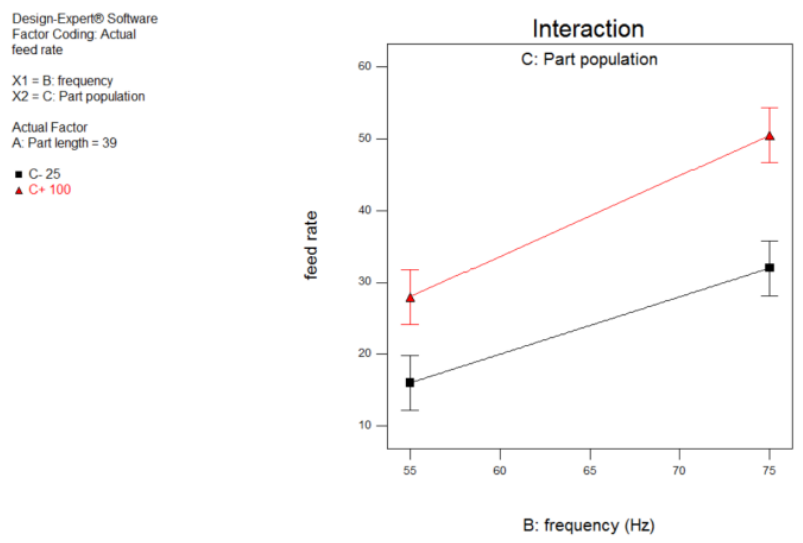

Fig. 8. Interaction Plot (frequency \& Part population)

The interaction plots are useful in judging the interaction between various parameters by looking at the parallelism of the lines. Higher the degree of parallelism, lesser is the extent of interaction between them.

Only the interaction plot of Part population and frequency depict synergic interaction. Although the lines on the plot do not cross each other but lack of their parallelism depicts significant interaction. While the interaction of part length and part population shows parallelism but they do intersect outside the graph, hence, this confirms negligible interaction between the two. Interaction plot of part length and frequency was not generated because combination of these two factors had no effect on response (as shown in figure 9).

\subsection{Final Equation in Terms of Actual Factors:}

Feed rate $=-29.88258+(0.098485 *$ Part length $)+$ $(0.69167 *$ frequency $)-(0.066515 *$ Part Population $)-$ (3.03030E-004 * Part length * Part Population) + (4.33333E-003* frequency * Part Population)

The equation in terms of actual factors can be used to make predictions about the response for given levels of each factor. Here, the levels should be specified in the original units for each factor. This equation should not be used to determine the relative impact of each factor because the coefficients are scaled to accommodate the units of each factor and the intercept is not at the center of the design space.

\section{SIGNIFICANCE OF VARIOUS PARAMETERS}

The Pareto Chart and the Half Normal Plot of the parameters determine the absolute importance and relative importance with respect to other parameters and draws a reference line on the chart, any effect that extends beyond this reference line is considered to be significant [4]. The effect of frequency (B) has the highest standardized effect on the feed rate followed by part population (C), BC, part length (A) and so on as depicted in figure 9 and 10.

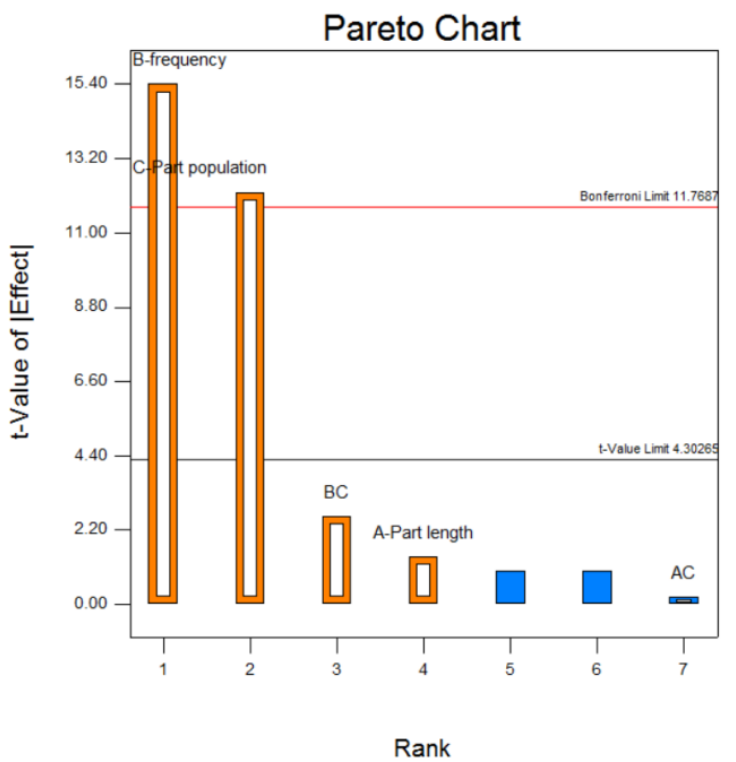

Fig. 9. Pareto Chart of the Standardized Effects 

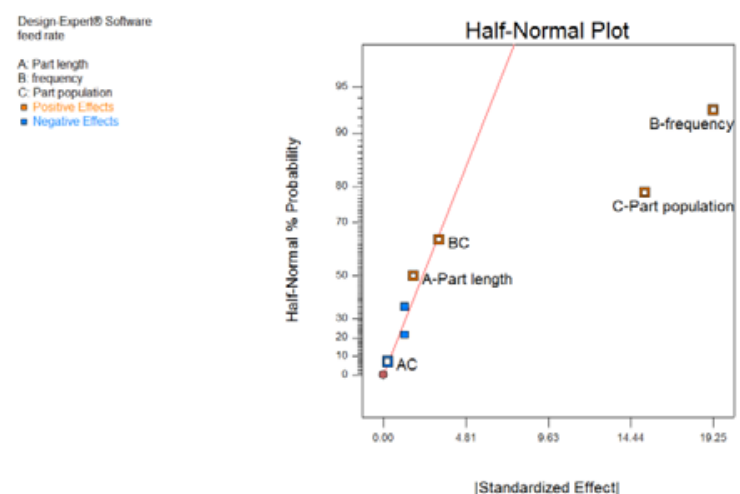

The $\mathrm{F}$ Value for a term is the test for comparing the variance associated with that term with the residual variance. It is the Mean Square for the term divided by the Mean Square for the Residual. $P$ value is the probability value that is associated with the $\mathrm{F}$ Value for this term. It is the probability of getting an F Value of this size if the term did not have an effect on the response.The calculated F-value and P-value are shown in Table 3. The Model F-value of 78.95 implies that there is a chance that such a large "Model F-value" could occur due to noise.

Fig. 10. Half normal Plot

\begin{tabular}{|l|r|r|r|r|l|}
\hline Source & Sum of Squares & DF & Mean Square & F Value & p-value Prob> F \\
\hline Model & 1233.63 & 5 & 246.72 & 78.95 & 0.0126 \\
\hline A-Part length & 2.49 & 1 & 2.49 & 0.80 & 0.4666 \\
\hline B-frequency & 101.31 & 1 & 101.31 & 32.42 & 0.0295 \\
\hline C-Part population & 0.89 & 1 & 0.89 & 0.29 & 0.6467 \\
\hline AC & 0.13 & 1 & 0.13 & 0.04 & 0.86 \\
\hline BC & 21.13 & 1 & 21.13 & 6.76 & 0.1215 \\
\hline Residual & 6.25 & 2 & 3.12 & & \\
\hline Cor Total & 1239.88 & 7 & & & \\
\hline
\end{tabular}

Table 3. Analysis of Variance

The terms that have a probability value less than 0.05 are significant. A probability value greater than 0.10 indicate the model terms are not significant. In this case, B (frequency) is the significant model term, while all others are insignificant.

\begin{tabular}{|l|l|l|l|}
\hline Std. Dev. & 1.77 & R-Squared & 0.995 \\
\hline Mean & 31.6 & Adj R-Squared & 0.9824 \\
\hline C.V. \% & 5.59 & Pred R-Squared & 0.9193 \\
\hline PRESS & 100 & Adeq Precision & 23.678 \\
\hline $\begin{array}{l}\text {-2 Log } \\
\text { Likelihood }\end{array}$ & 20.73 & BIC & 33.2 \\
\hline & & AICc & 116.73 \\
\hline
\end{tabular}

Table 4. Diagnostics case statics

R square measures the proportion of total variability explained by the model. From Table 4, the value of $\mathrm{R}$ squared is 0.995 . A potential problem with this statistic is that it always increases as factors are added to the model even if these factors are insignificant. So the adjusted R squared was calculated to be 0.9824 .

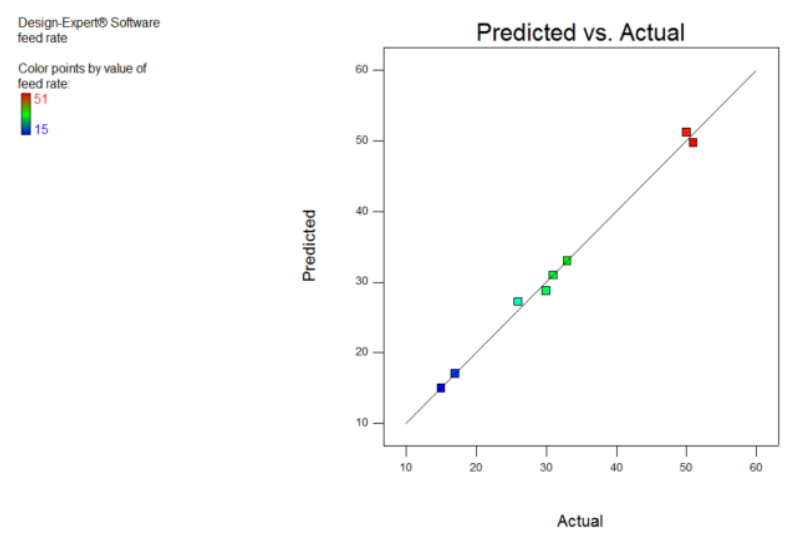

Fig. 11. Predicted vs Actual value Plot
The "Predicted R-Squared" of 0.9193 is in reasonable agreement with the "Adj R-Squared" of 0.9824. “Adeq Precision” measures the signal to noise ratio. A ratio greater than 4 is desirable. Hence a ratio of 23.678 indicates an adequate signal. This model can be used to navigate the design space. The Diagnostics Case Statistics compares the actual and predicted values and obtains the residual as shown in figure 11 and 12.

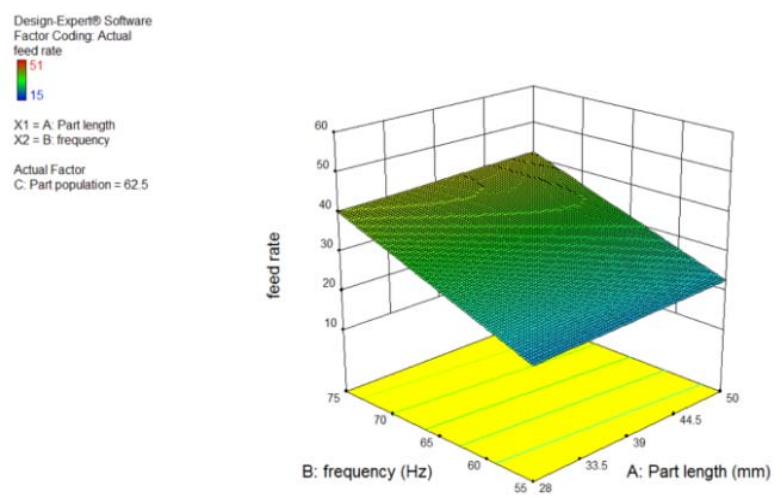

Fig. 12. Surface Plot

\section{OPTIMIZATION OF FEED RATE}

Beginning of the optimization procedure starts from picking several starting points from which the optimal factor is searched. There are two types of solutions for the search:

Local solution: There is a local solution for each starting point. These solutions are the combination of parameters beginning from a particular starting point.

Global solution: The global solution is the best of all the local solutions. The global solution is obtained by combining the parameters in such a way, that 
desired response is obtained. For each of the local solution, predicted value of the response is calculated.

Desirability is rated on a scale of 0 to 1 and 1 being the most desirable solution.
Solutions found for the constraints in Table 5 are shown in Table 6.

A total of 79 solutions were obtained, out of which 10 most desirable solutions are tabulated below.

\begin{tabular}{|l|l|r|r|r|r|r|}
\hline Name & Goal & $\begin{array}{l}\text { Lower } \\
\text { Limit }\end{array}$ & $\begin{array}{l}\text { Upper } \\
\text { Limit }\end{array}$ & $\begin{array}{l}\text { Lower } \\
\text { Weight }\end{array}$ & $\begin{array}{l}\text { Upper } \\
\text { Weight }\end{array}$ & Importance \\
\hline A: Part Length & Is in range & 28 & 50 & 1 & 1 & 3 \\
\hline B: Frequency & Is in range & 55 & 75 & 1 & 1 & 3 \\
\hline C: Part Population & Is in range & 25 & 100 & 1 & 1 & 3 \\
\hline
\end{tabular}

Table 5. Constraints

\begin{tabular}{|c|c|c|c|c|c|c|}
\hline Number & Part Length & Frequency & Part Population & Feed Rate & Desirability & \\
\hline 1 & 49.996 & 74.953 & 99.745 & 51.134 & $\underline{1}$ & Selected \\
\hline 2 & 47.661 & 74.991 & 99.988 & 51.078 & 1 & \\
\hline 3 & 48.131 & 74.971 & 99.831 & 51.048 & 1 & \\
\hline 4 & 49.946 & 74.95 & 99.333 & 51.028 & 1 & \\
\hline 5 & 47.535 & 74.964 & 99.981 & 51.037 & 1 & \\
\hline 6 & 48.497 & 74.997 & 99.477 & 51.017 & 1 & \\
\hline 7 & 47.056 & 74.984 & 99.893 & 51.005 & 1 & \\
\hline 8 & 48.945 & 74.999 & 99.783 & 51.124 & 1 & \\
\hline 9 & 49.101 & 74.992 & 99.564 & 51.074 & 1 & \\
\hline 10 & 49.441 & 74.917 & 99.536 & 51.005 & 1 & \\
\hline
\end{tabular}

Table 6. Solutions

\begin{tabular}{|l|l|c|l|l|l|l|}
\hline Factor & $\begin{array}{l}\text { Coefficient } \\
\text { Estimate }\end{array}$ & DF & $\begin{array}{l}\text { Standard } \\
\text { Error }\end{array}$ & $\mathbf{9 5 \%}$ CI Low & 95\% CI High & VIF \\
\hline Intercept & -29.88 & 1 & 9.08 & -68.93 & 9.17 & \\
\hline A-Part Length & 0.098 & 1 & 0.11 & -0.38 & 0.57 & 3.78 \\
\hline B-Frequency & 0.69 & 1 & 0.12 & 0.17 & 1.21 & 3.78 \\
\hline $\begin{array}{l}\text { C-Part } \\
\text { Population }\end{array}$ & -0.067 & 1 & 0.12 & -0.60 & 0.47 & 55.8 \\
\hline AC & $-3.03 \mathrm{E}-04$ & 1 & $1.52 \mathrm{E}-03$ & $6.82 \mathrm{E}-03$ & $6.22 \mathrm{E}-03$ & 16.4 \\
\hline BC & $4.33 \mathrm{E}-03$ & 1 & $1.67 \mathrm{E}-03$ & $2.84 \mathrm{E}-03$ & 0.012 & 46 \\
\hline
\end{tabular}

Table 7. Formulation of Mathematical Relation

\section{CONCLUSION}

Optimization of feed rate of the Vibratory Bowl Feeder has been done using an authentic statistical model based on full factorial experiment design. This model can be used to explain $91 \%$ of variability in new data. Frequency and part population are found to be the most significant parameters followed by the interaction of these two parameters taken together and part length was found to be least significant.

\section{REFERENCES}

[1] Groover M.P., Automation, Production Systems, and Computer-Integrated Manufacturing, Second Edition, Prentice Hall of India Pvt. Ltd., New Del

[2] Hesse S., "Rationalisation of small workpiece feeding", Festo AG \& Co., 2000

[3] Ujjwal Jindal, Shrey Jain, Piyush, Pradeep Khanna, Graphical Analysis of a Vibratory Bowl Feeder for Clip shaped Components, IJISET - International Journal of Innovative Science, Engineering \& Technology, Vol. 4 Issue 2, February 2017

[4] Astha Kukreja, Pankaj Chopra, Akshay Aggarwal, Pradeep Khanna, "Statistical Modeling Approach for Optimization of a Stationary Hook Hopper", 2nd International Conference on Mechanical, Industrial, and Manufacturing Technologies (MIMT 2011), pp.V1-594-598

[5] Tanushi Pandey, Vishesh Garg, Sheetal Bhagat, Pradeep Khanna, Mathematical Analysis of Vibratary Bowl Feeder, International Journal of Latest Trends in Engineering and Technology (IJLTET)

Authors: Ujjwal Jindal, U.G. Student, Shrey Jain, U.G. Student, Piyush, U.G. Student, Pradeep Khanna, Associate Professor, Department of Manufacturing Processes and Automation Engineering, Netaji Subhas Institute of Technology, Delhi, India.

E-mail: shreyjain1@gmail.com 